\title{
Delusional Misidentification Syndrome with Response to Donepezil and Behavioral Intervention in a Patient with Dementia
}

\author{
Muhammad Ubaid Hafeez ${ }^{1 \#}$, Katherine T. Mun ${ }^{2 \#}$, Haris Kamal ${ }^{1}$ and Kinga Szigeti ${ }^{{ }^{*}}$ \\ ${ }^{1}$ Department of Neurology, The State University of New York at Buffalo, USA \\ ${ }^{2}$ Department of Psychiatry, The State University of New York at Buffalo, USA \\ *Corresponding author: Kinga Szigeti, Department of Neurology, University at Buffalo, 100 High Street, E2, Buffalo, New York, 14203, USA, Tel: (716) 859-3539; E-mail: \\ szigeti@buffalo.edu
}

Received date: June 11, 2017, Accepted date: July 17, 2017, Published date: July 21, 2017

Copyright: @2017 Hafeez MU, et al. This is an open-access article distributed under the terms of the Creative Commons Attribution License, which permits unrestricted use, distribution, and reproduction in any medium, provided the original author and source are credited.

\# The first two authors contributed equally to the manuscript.

\begin{abstract}
Introduction: Delusional Misidentification Syndrome (DMS) encompasses a group of disorders in which a person persistently believes the identity of people, places, or objects are altered. Historically, described in psychotic disorders, DMS prevalence is $15.8 \%$ in Alzheimer's disease (AD) and $16.6 \%$ in dementia with Lewy bodies (DLB). We present a case of DMS in a patient with dementia that incorporates elements of mirrored self-misidentification and phantom boarder syndrome and therapeutic response to a combination of a behavioral intervention and donepezil.
\end{abstract}

Case: 75-year-old white female presented with a four months history of DMS and visual hallucinations. Patient perceived her own reflection in picture glass as an older lady who was trying to steal her "boyfriends." Her "boyfriends" were three pictures of soldiers in her apartment. MMSE was 27/30 (WORLD) and 23/30 (Serial 7s). MRI showed biparietal and right hippocampal atrophy. NPT showed impaired language, spatial abilities, memory, and executive control. She scored $<1$ percentile on category word fluency, judgement of line orientation, raw complex figures and Beery VMI. Patient was diagnosed with probable AD, using NINCDS-ADRDA and findings on neuropsychological testing (NPT) and MRI. DLB was excluded using McKeith's criteria. After a failed trial of risperidone, she received donepezil and family was instructed to remove photographs. MMSE stable with resolution of the mirrored selfmisidentification at 4 months follow up.

Conclusion: Patient's poor response to risperidone is consistent with previous studies suggesting limitations of antipsychotic treatment for psychotic symptoms in $A D$. Removal of potential symptom trigger along with an acetylcholinesterase inhibitor resulted in remission for up to 4 months. The potentiating effect of donepezil on the cholinergic component of the visuo-amygdaloid pathway/dorsal visual pathway may account for these changes.

Keywords: Delusional misidentification syndrome; Dementia; Poserior cortical atrophy; Alzheimer's disease; Cholinesterase inhibitors

\section{Introduction}

Delusional misidentification syndromes (DMS) encompass a group of delusional disorders in which patients persistently believe that people, places, objects, or events have somehow been altered. They are usually associated with schizophrenia spectrum, but also reported with organic disorders like dementias, epilepsy, traumatic brain injury, subarachnoid hemorrhage [1] and stroke [2]. The prevalence in Alzheimer's dementia (AD) and dementia with Lewy Bodies (DLB) is estimated at $16 \%$, with the prevalence somewhat higher in DLB [3]. We present a case that incorporated elements of mirrored selfmisidentification (delusion that one's reflection in the mirror is another person) and phantom boarder (delusion that someone uninvited is living in one's house), resolved with combination of behavioral intervention and donepezil.

\section{Case Report}

Ms. $\mathrm{H}$ was a 75 year old female who presented with a four months history of visual hallucinations (VH) and DMS. She reported living in her apartment with 3 boyfriends and recently noticed an older woman trying to steal the boyfriends from her. Ms. $\mathrm{H}$ called the police several times because of the older woman. According to her daughter, the "boyfriends" were photographs of three soldiers, pictured from waist up (no legs visible in the pictures). Ms. $\mathrm{H}$ believed that those men lost their legs in a war. She carried those pictures around, believing they men couldn't walk and needed her help. She acknowledged that they were photographs but believed that they had material bodies with certain needs. One of the pictures were of her late husband in his youth but patient didn't acknowledge it. Ms. H also reported that she could see the reflection of the older woman trying to climb onto her boyfriends which was in fact her own reflection in the glass of picture frames. She claimed that old woman in reflection always wore the same jewelry and clothes as her which she must had stolen from her as well. 
Citation: Hafeez MU, Mun KT, Kamal H, Szigeti K (2017) Delusional Misidentification Syndrome with Response to Donepezil and Behavioral Intervention in a Patient with Dementia. J Aging Sci 5: 181. doi:10.4172/2329-8847.1000181

Page 2 of 6

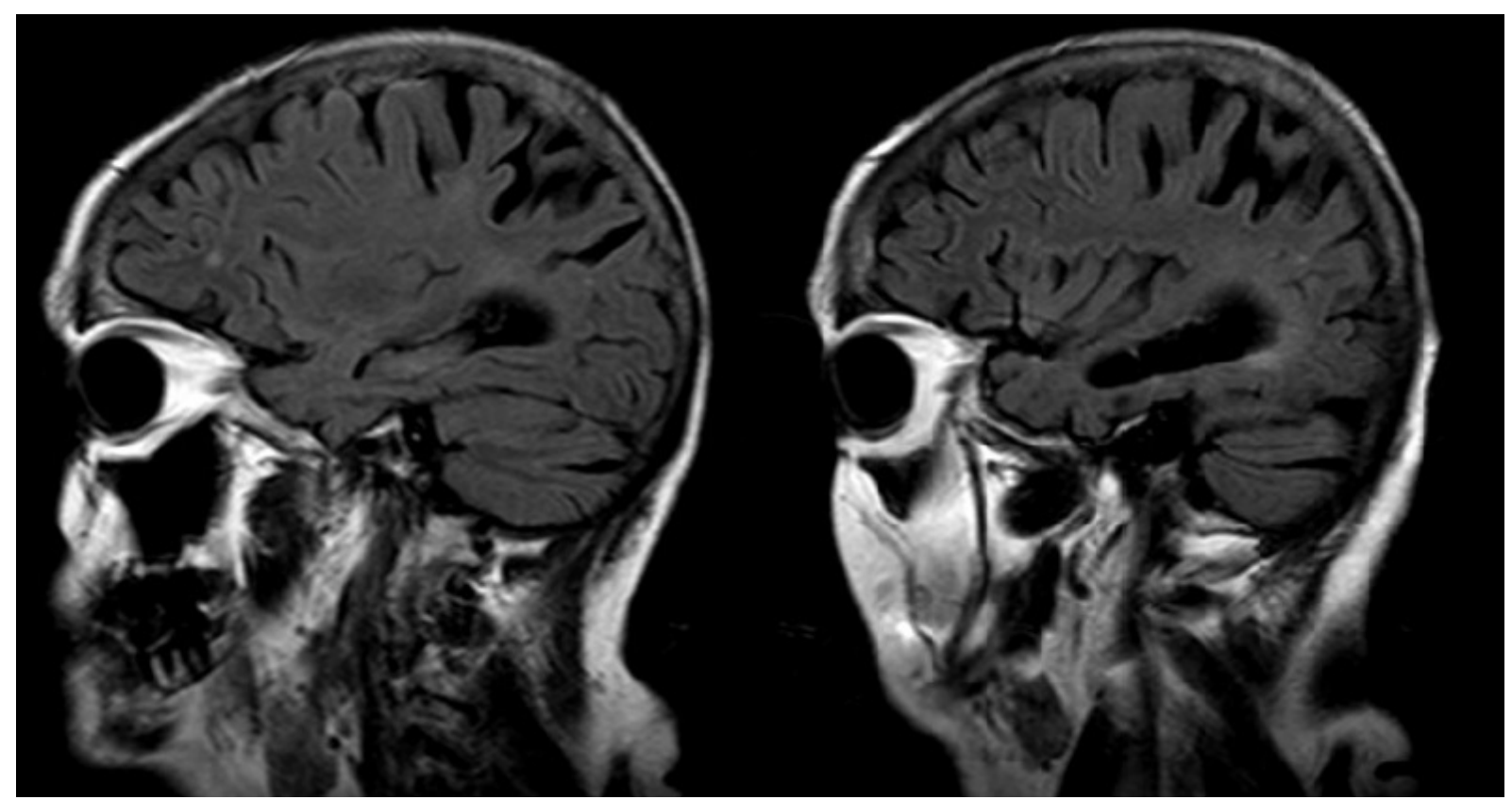

Figure 1: T1 sagittal views demonstrating bi-parietal atrophy.

She scored 27 on MMSE WORLD and 23 with Serial $7 \mathrm{~s}$. Neuropsychological testing (NPT) showed impaired language, spatial abilities, immediate memory and executive control (Table 1). Dalyed recall was borderline abnormal. MRI showed bi-parietal, occipital and right hippocampal atrophy (Figures 1-3). She presented to us after a failed trial of risperidone. Given that her presentation and workup was more consistent with $\mathrm{AD}$, she was started on donepezil $5 \mathrm{mg}$, titrated to $10 \mathrm{mg} /$ day. The family was also instructed to put the photographs away to remove the presumed trigger.

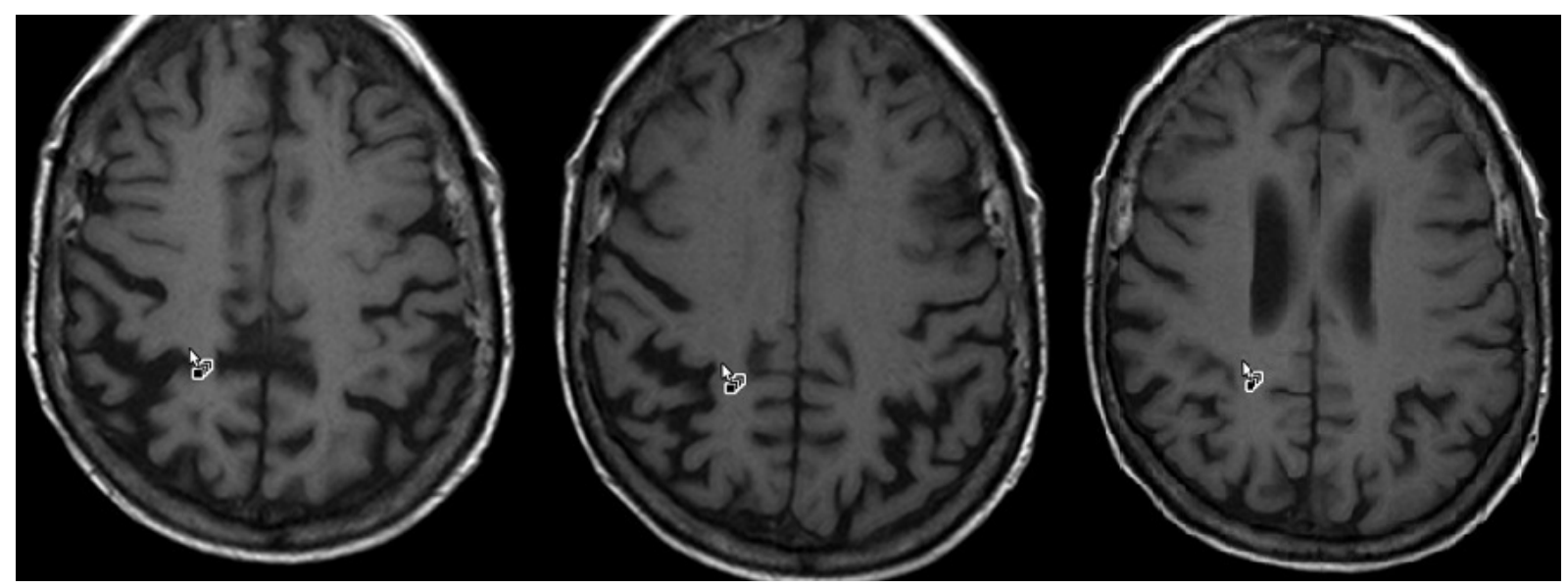

Figure 2: T1 axial views demonstrating bi-parietal atrophy.

At 4 months follow-up, she demonstrated marked improvement stating, "That old lady is finally gone!" The photographs were put back after 2 weeks, as per her request, without recurrence of DMS. She still acknowledged the presence of her soldier friends but it was not distressful. Her MMSE remained stable. 
Citation: Hafeez MU, Mun KT, Kamal H, Szigeti K (2017) Delusional Misidentification Syndrome with Response to Donepezil and Behavioral Intervention in a Patient with Dementia. J Aging Sci 5: 181. doi:10.4172/2329-8847.1000181

Page 3 of 6

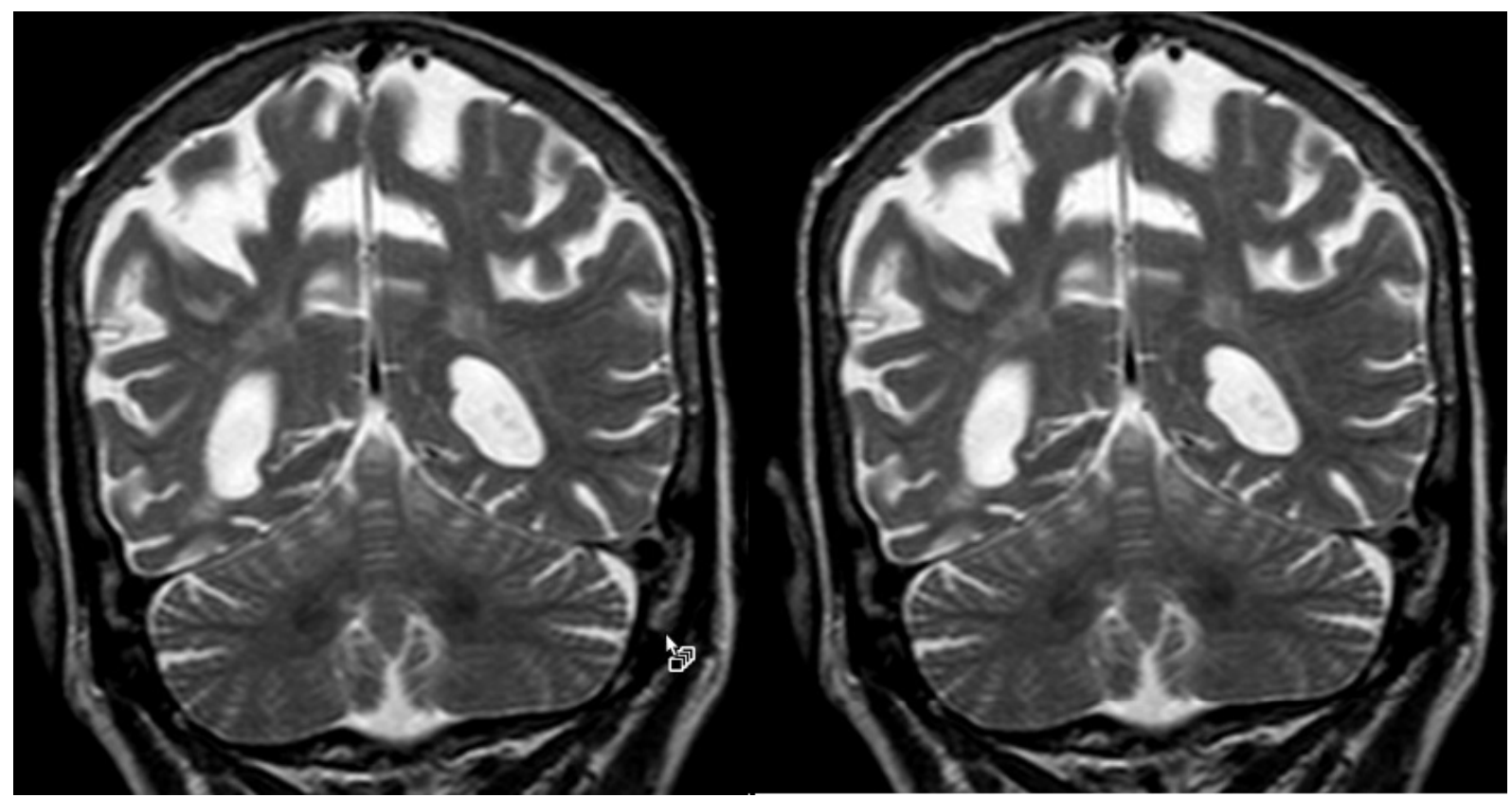

Figure 3: T2 coronal views demonstrating the loss of brain volume.

\section{Discussion}

Patient was diagnosed with probable AD, using NINCDS-ADRDA which was further supported on NPT and MRI [4]. Patient did not meet the Mckeith's Criteria for probable DLB as no cognitive fluctuations, parkinsonism or REM sleep behavioral disorder were observeded [5]. Possible DLB still remained in differential given prominent visuospatial deficits, visual hallucinations $(\mathrm{VH})$, exectutive dysfunction and the fact that AD and DLB frequently overlap. Further diagnositic modalities including transcranial magnetic stimulation study Posterior cortical atrophy (PCA) variant was also a consideration given prominent space and object percepion deficits, constructional dysparaxia seen on NPT and marked parieto-occipital and temporal atrophy seen on MRI. However, our patient lacked other frequently seen PCA features including Balint's syndrome (simultanagnosia, oculomotor apraxia, optic ataxia) or Gerstmann's syndrome (acalculia, agraphia, finger agnosia, left/right disorientation) [6].

\begin{tabular}{|c|c|c|c|c|c|}
\hline Cognitive Test & Description & $\begin{array}{l}\text { (Raw scores \& } \\
\text { Interpretation) }\end{array}$ & $\begin{array}{l}\text { Percentiles } \\
\text { adjusted for age }\end{array}$ & $\begin{array}{l}\text { Percentiles } \\
\text { adjusted for age, } \\
\text { sex \& Education }\end{array}$ & Interpretation \\
\hline MMSE & $\begin{array}{l}\text { Used as baseline to } \\
\text { assess general cognitive } \\
\text { ability }\end{array}$ & $\begin{array}{l}\text { World } 27, \\
\text { serial seven } 23\end{array}$ & - & - & - \\
\hline NAART IQ & $\begin{array}{l}\text { Estimated premorbid } \\
\text { intelligence }\end{array}$ & 110 & - & - & High Average \\
\hline Boston naming test & $\begin{array}{l}\text { Confrontational } \\
\text { word retrieval }\end{array}$ & 46 & 5 & - & Borderline \\
\hline CIFA letter word fluency & $\begin{array}{l}\text { Language and } \\
\text { academic skills }\end{array}$ & 26 & 42 & 58 & Normal \\
\hline CIFA category word fluency & $\begin{array}{l}\text { Language and } \\
\text { academic skills }\end{array}$ & 21 & 1 & 1 & Defect \\
\hline $\begin{array}{l}\text { Beery Developmental test of } \\
\text { visual-motor integration }\end{array}$ & $\begin{array}{l}\text { Visual-motor } \\
\text { construction } \\
\text { Integration }\end{array}$ & 18 & 1 & - & Defect \\
\hline Clock drawing test & $\begin{array}{l}\text { Visual-motor } \\
\text { construction, visual- } \\
\text { motor planning and } \\
\text { organization }\end{array}$ & - & - & - & - \\
\hline
\end{tabular}


Citation: Hafeez MU, Mun KT, Kamal H, Szigeti K (2017) Delusional Misidentification Syndrome with Response to Donepezil and Behavioral Intervention in a Patient with Dementia. J Aging Sci 5: 181. doi:10.4172/2329-8847.1000181

Page 4 of 6

\begin{tabular}{|c|c|c|c|c|c|}
\hline $\begin{array}{l}\text { Benton judgement of } \\
\text { line orientaion test }\end{array}$ & $\begin{array}{l}\text { Line and angle } \\
\text { discrimintaion }\end{array}$ & 0 & $<1$ & - & Defect \\
\hline Benton facial recognition test & $\begin{array}{l}\text { Facial recgonition, } \\
\text { Capgras-like visual } \\
\text { decomposition of face }\end{array}$ & 17 & - & - & Defect \\
\hline Rey complex figure copy & $\begin{array}{l}\text { Visual-motor } \\
\text { construction and } \\
\text { Organization }\end{array}$ & 5 & $<1$ & $<1$ & Defect \\
\hline Hopkins verbal learnig test (trials $1-3$ ) & $\begin{array}{l}\text { Verbal short term } \\
\text { memory }\end{array}$ & 14 & 8 & 14 & Borderline \\
\hline $\begin{array}{l}\text { Hopkins verbal learning test (delayed } \\
\text { recall) }\end{array}$ & $\begin{array}{l}\text { delayed verbal memory } \\
\text { and recall (delay 20-25 } \\
\text { mins) }\end{array}$ & 6 & 24 & 34 & Normal \\
\hline Hopkins verbal learning test retention (\%) & Verbal memory retention & 100 & 84 & 86 & Normal \\
\hline Hopkins delayed recognition index & - & 6 & 2 & 4 & Borderline \\
\hline $\begin{array}{l}\text { WMS-R logical memory } \\
\text { trial-1 }\end{array}$ & $\begin{array}{l}\text { Logical learning and } \\
\text { memory }\end{array}$ & 11 & 2 & 2 & Defect \\
\hline $\begin{array}{l}\text { WMS-R logical memory } \\
\text { trial-2 }\end{array}$ & $\begin{array}{l}\text { Delayed logical memory } \\
\text { and recall (delay: } 20-25 \\
\text { mins) }\end{array}$ & 9 & 8 & 12 & Borderline \\
\hline $\begin{array}{l}\text { Wms-R Visual Reproduction } \\
\text { Trial-1 }\end{array}$ & $\begin{array}{l}\text { Visual learning and } \\
\text { memory }\end{array}$ & 22 & 18 & 21 & Normal \\
\hline $\begin{array}{l}\text { Wms-R Visual Reproduction } \\
\text { Trial-2 }\end{array}$ & $\begin{array}{l}\text { Delayed visual memory } \\
\text { and recall (delay: } 20-25 \\
\text { mins) }\end{array}$ & 3 & 10 & 12 & Borderline \\
\hline Wais iii digit span forward & $\begin{array}{l}\text { Short-term memory, } \\
\text { working memory and } \\
\text { recall }\end{array}$ & 5 & 16 & 18 & Normal \\
\hline Wais iii digit span backward & $\begin{array}{l}\text { Short-term memory, } \\
\text { working memory and } \\
\text { recall }\end{array}$ & 3 & 5 & 4 & Borderline \\
\hline $\begin{array}{l}\text { Wais iii total digit span (forward + } \\
\text { backward) }\end{array}$ & - & 8 & 7 & 7 & Borderline \\
\hline $\begin{array}{l}\text { Trail making test-a } \\
\text { (secs to complete) }\end{array}$ & $\begin{array}{l}\text { Visual attention and } \\
\text { executive control }\end{array}$ & 49 & 34 & 38 & Normal \\
\hline $\begin{array}{l}\text { Trial making test-b } \\
\text { (secs to complete) }\end{array}$ & $\begin{array}{l}\text { Visual attention and } \\
\text { executive control }\end{array}$ & $d / c$ & - & - & Defect \\
\hline $\begin{array}{l}\text { DKEFS sorting test - } \\
\text { correct sorts }\end{array}$ & $\begin{array}{l}\text { Verbal and spatial } \\
\text { concept formation and } \\
\text { executive control }\end{array}$ & 2 & 2 & - & Defect \\
\hline $\begin{array}{l}\text { DKEFS sorting test - } \\
\text { description score }\end{array}$ & $\begin{array}{l}\text { Verbal and spatial } \\
\text { concept formation and } \\
\text { executive control }\end{array}$ & 6 & 2 & - & Defect \\
\hline $\begin{array}{l}\text { DKEFS sorting test } \\
\text { - repeated sorts }\end{array}$ & $\begin{array}{l}\text { Verbal and spatial } \\
\text { concept formation and } \\
\text { executive control }\end{array}$ & 1 & 50 & - & Normal \\
\hline Geriatric depression scale & - & 7 & - & - & Mild \\
\hline Purpose in life scale & - & 3 & - & - & Average \\
\hline Neuropsychiatric inventory & - & 32 & - & - & Moderate \\
\hline $\begin{array}{l}\text { Lawton brody adl/iadl, } \\
\text { Self report }\end{array}$ & $\begin{array}{l}\text { Self-reported activities } \\
\text { of daily living }\end{array}$ & 2 & 8 & 7 & Borderline \\
\hline
\end{tabular}


Citation: Hafeez MU, Mun KT, Kamal H, Szigeti K (2017) Delusional Misidentification Syndrome with Response to Donepezil and Behavioral Intervention in a Patient with Dementia. J Aging Sci 5: 181. doi:10.4172/2329-8847.1000181

Page 5 of 6

Lawton brody adl/iadl, infromant report
Informant reported 4 activities of daily living

Table 1: Neuropsychiatric test results.

Neuroanatomical correlations for $\mathrm{VH}$ and DMS include right mesiotemporal atrophy or involvement of ventral and dorsal visual streams. Ismail Z., in his review reported that delusions in $\mathrm{AD}$ are predominantly a right hemispheric phenomenon with medial temporal lobes specifically involved in DMS [7]. A disconnection from right temporo-limbic regions may result into lack of insight into the visual stimuli and hence the wrong emotional responses attached to them.

\begin{tabular}{|c|c|c|c|c|c|}
\hline Study & \# of Patients & DMSs Type & Underlying Pathology & Treatment & Outcome \\
\hline Gil-Ruiz, et al. & 1 & Mirror Sign & Probable DLB & Behavioral Intervention & Mirror Sign replaced by Imposters/ another DMS \\
\hline Oulis $P$, et al. & 1 & Capgras & $\begin{array}{l}\text { Paranoid } \\
\text { Schizophrenia } \\
\text { complicated by } \\
\text { Vascular Dementia }\end{array}$ & $\begin{array}{l}\text { Donepezil, } \\
\text { Olanzapine }\end{array}$ & Resolved \\
\hline $\begin{array}{l}\text { Peritogiannis } \\
\text { V, et al. }\end{array}$ & 1 & Capgras & Vascular Dementia & Donepezil & Resolved \\
\hline Reimers, et al. & 2 & Capgras & DLB & Donepezil & Resolved \\
\hline Roane, et al. & 3 & $\begin{array}{l}\text { Capgras, } \\
\text { Reduplication }\end{array}$ & PDD & Clozapine & Resolved in $2 / 3$ cases \\
\hline Shiotsuki & 1 & Capgras & PDD & $\begin{array}{l}\text { Failed trial with Donepezil, } \\
\text { Increased dose of levodopa/ } \\
\text { carbidopa }\end{array}$ & \\
\hline Sutton & 1 & Capgras & Dementia NOS & Quetiapine & Improved \\
\hline Marantz & 1 & Capgras & DLB & & $\begin{array}{l}\text { Spontaneous resolution with worsening of the } \\
\text { disease }\end{array}$ \\
\hline $\begin{array}{l}\text { Pagonabarrag } \\
\text { a J, et al. }\end{array}$ & 5 & & PDD & $\begin{array}{l}\text { A) Quetiapine in } 3 \text { patients. } \\
\text { B) Ziprasidone in } 1 \text { patients } \\
\text { C) Riviastigmine initiated in } 1 \\
\text { patient } 4 / 5 \text { patients were } \\
\text { already on it }\end{array}$ & $\begin{array}{l}\text { Improvement with Quetiapine in } 2 / 3 \text { patients. } \\
\text { Improvement with Ziprasidone } 1 / 1 \text { patient. } \\
\text { Marked improvement was observed in the one in } \\
\text { which therapy was initiated with rivastigmine }\end{array}$ \\
\hline
\end{tabular}

Table 2: Cases reporting successful management of DMS in neurodegenerative disorders

The involvement of ventral (occipito-temporal) and dorsal (occipito-parietal) visual streams can also explain these symptoms. These pathways, through connections to the limbic system, are involved in processing facial recognition and generating affective responses, based on the familiarity to the stimulus. Any disruption along these pathways can lead to a false interpretation of the visual stimulus [8]. Reeves et al. suggested a role of ventral visual pathway based on the poor performance on rapid visual processing tests that have documented association with these pathways [9]. Diffusion tensor imaging studies also showed the involvement of an indirect occipito-temporal pathway (inferior longitudinal fasciculus) [10]. Furthermore, post-mortem studies have shown increased tax burden along these pathways as well as in right hippocampal and parahippocampal regions [11-13].

Several studies have described the role of cholinesterase inhibitors (ChEI) in managing neuropsychiatric symptoms of $\mathrm{AD}, \mathrm{DLB}$, and Parkinon's disease dementia (PDD) [14-16]. ChEI have also been reported to be beneficial in managining DMS in cases of DLB [17], vascular dementia [18] and PDD [19]. In addition, antipsychotics and simple behavioral interventions have been used for DMS with some success, although antipsychotics are not without risk and side effects in such patients [20,21] (see Table 2). In our case, a combination of behavioral modification with donepezil was effective. Further doubleblind studies are needed to evaluate the role of ChEI in treating DMS associated with neurodegeneration.

\section{References}

1. Cipriani G, Vedovello M, Ulivi M, Lucetti C, Di Fiorino A, et al. (2013) Delusional Misidentification Syndromes and Dementia A Border Zone Between Neurology and Psychiatry. Am J Alzheimer's Disease Dementias 28: 671-678.

2. Villarejo A, Martin VP, Moreno-Ramos T, Camacho-Salas A, PortaEtessam J, et al. (2011) Mirrored-self misidentification in a patient without dementia: evidence for right hemispheric and bifrontal damage. Neurocase 17: 276-284.

3. Harciarek M, Kertesz A (2008) The prevalence of misidentification syndromes in neurodegenerative diseases. Alzheimer Disease \& Associated Disorders 22: 163-169. 
Citation: Hafeez MU, Mun KT, Kamal H, Szigeti K (2017) Delusional Misidentification Syndrome with Response to Donepezil and Behavioral Intervention in a Patient with Dementia. J Aging Sci 5: 181. doi:10.4172/2329-8847.1000181

Page 6 of 6

4. McKhann G, Drachman D, Folstein M, Katzman R, Price D, et al. (1984) Clinical diagnosis of Alzheimer's disease Report of the NINCDS-ADRDA Work Group ${ }^{*}$ under the auspices of Department of Health and Human Services Task Force on Alzheimer's Disease. Neurology 34: 939.

5. McKeith IG, Dickson DW, Lowe J, Emre M, O'Brien JT, et al. (2005) Diagnosis and management of dementia with Lewy bodies: third report of the DLB Consortium. Neurology 65: 1863-1872.

6. Crutch SJ, Schott JM, Rabinovici GD, Murray M, Snowden JS, et al. Consensus classification of posterior cortical atrophy. Alzheimer's \& Dementia.

7. Ismail Z, Nguyen MQ, Fischer CE, Schweizer TA, Mulsant BH (2012) Neuroimaging of delusions in Alzheimer's disease. Psychiatry Res 202: 89-95.

8. Ellis HD, Young AW (1990) Accounting for delusional misidentifications. The British J Psychiatry 157: 239-248.

9. Reeves SJ, Clark-Papasavas C, Gould RL, Ffytche D, Howard RJ (2015) Cognitive phenotype of psychotic symptoms in Alzheimer's disease: evidence for impaired visuoperceptual function in the misidentification subtype. Int J Geriatr Psychiatry 30: 1147-1155.

10. Kantarci K, Avula R, Senjem M, Samikoglu A, Zhang B, et al. (2010) Dementia with Lewy bodies and Alzheimer disease Neurodegenerative patterns characterized by DTI. Neurology 74: 1814-1821.

11. Ferman TJ, Arvanitakis Z, Fujishiro H, Duara R, Parfitt F, et al. (2013) Pathology and temporal onset of visual hallucinations, misperceptions and family misidentification distinguishes dementia with Lewy bodies from Alzheimer's disease. Parkinsonism Relat Disord 19: 227-231.

12. Förstl H, Burns A, Levy R, Cairns N (1994) Neuropathological correlates of psychotic phenomena in confirmed Alzheimer's disease. British J Psychiatry 165: 53.
13. Mukaetova-Ladinska E, Harrington C, Roth M, Wischik C (1993) Biochemical and anatomical redistribution of tau protein in Alzheimer's disease. The Am J Pathology 143: 565.

14. Rogers SL, Farlow MR, Doody RS, Mohs R, Friedhoff LT (1998) A 24week, double-blind, placebo-controlled trial of donepezil in patients with Alzheimer's disease. Donepezil Study Group. Neurology 50: 136-145.

15. Szigeti K, Hafeez MU (2015) Exploring the role of donepezil in dementia with Lewy bodies. Drugs of today (Barcelona, Spain: 1998) 51: 579-590.

16. Oh YS, Kim JS, Lee PH (2015) Effect of Rivastigmine on Behavioral and Psychiatric Symptoms of Parkinson's Disease Dementia. J Movement Disorders 8: 98-102.

17. Reimers K, Emmert N, Shah H, Benedict RH, Szigeti K (2014) Capgraslike visual decomposition in Lewy body dementia with therapeutic response to donepezil. Neurology Clinical Practice 4: 467-469.

18. Oulis P, Dimitrakopoulos S, Konstantakopoulos G, Tsaltas E, Kollias K (2012) Capgras delusion in paranoid schizophrenia complicated by vascular dementia. The J Neuropsychiatry and Clinical Neurosciences 24 : 28.

19. Pagonabarraga J, Llebaria G, García-Sánchez C, Pascual-Sedano B, Gironell A, et al. (2008) A prospective study of delusional misidentification syndromes in Parkinson's disease with dementia. Movement Disorders 23: 443-448.

20. Roane DM, Rogers JD, Robinson JH, Feinberg TE (1998) Delusional Misidentification In Association With Parkinsonism. The J Neuropsychiatry And Clinical Neurosciences.

21. Gil-Ruiz N, Osorio RS, Cruz I, Aguera-Ortiz L, Olazaran J, et al. (2013) An effective environmental intervention for management of the 'mirror sign' in a case of probable Lewy body dementia. Neurocase 19: 1-13. 